\title{
Gdzie jest gej? \\ O (nazwach) przestrzeni w pierwszych polskich pismach gejowskich
}

„Dwie zakonnice. Przechodzą szybkim krokiem, nawet nie rzuciwszy okiem na

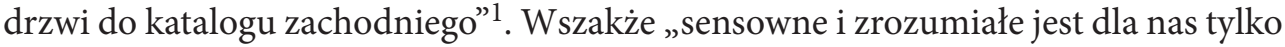
to, co porusza się po torach naszego świata"2. Pikiety, Broadway i punkt Pod Obrazem stają się heterotopiamii ${ }^{3}$, realnymi miejscami łączącymi w sobie kilka przestrzeni, wymiarów, do których z pozoru wejść może każdy, ale nie każdy — nomen omen w rzeczywistości się w nich znajdzie. Bez znajomości odpowiedniego kontekstu toaleta dworcowa już zawsze pozostanie toaletą, a sam Centralny - tylko stacją PKP.

Pisząc o gejowskich przestrzeniach ujętych w polskich pedalskich ${ }^{4}$ zinach i czasopismach, mam na myśli przestrzenie realne, tj. fizyczne (toalety, parki, sauny, etc.) oraz przestrzenie mentalne, istniejące jedynie w świadomości (i języku) ich użytkowników. Do tych drugich zaliczam np. „szafę” („wychodzić z szafy” — ang. „coming out of the closet"), która stała się metaforą - z jednej strony ukrycia, getta, a z drugiej azylu i miejsca bezpiecznego, $\mathrm{z}$ dala od oceny heteronormatywnego społeczeństwa.

Pierwsze polskie pisma gejowskie (choć trafniejszym byłoby określanie ich „pedalskimi” (jak wyżej) lub „ciotowskimi”) zalicza się m.in. do zinów, czyli amatorskich, niezależnych czasopism o małym nakładzie, adresowanych do homogenicznej

1 M. Krzeszowiec, Ból istnienia, „Inaczej” 1991, nr 15, s. 9.

2 M. Ajvaz, Inne miasto, [w:] idem, Morderstwo w hotelu Intercontinental. Powrót starego warana. Inne miasto, przeł. L. Engelking, Sejny 2005, s. 174.

3 M. Foucault, Inne przestrzenie, przeł. A. Rejniak-Majewska, „Teksty Drugie” 2005, nr 6, s. 117-125.

4 Określenia „pedalski” będę używał naprzemiennie z „gejowski” i „ciotowski”. Wszystkie trzy stosuję w pełni neutralnie, bez ich (potocznego) negatywnego nacechowania czy wulgarności w ogóle, co wyjaśniam w kolejnym akapicie. 
społeczności ${ }^{5}$. Redakcja „Filo” (pierwszy numer wydano w 1986 roku) efekt swojej pracy definiuje następująco: „Pismo należy do tzw. zinów (pism drugiego obiegu ${ }^{6}$ ), działa niezależnie i prywatnie - no bo w końcu, kto nam pomoże, jak nie my sami”7. Pisma powstałe w późniejszych latach (np. „Inaczej” wydawane przez 12 lat od 1990 roku) kategoryzuje się już jako czasopisma ${ }^{8}$ per se, choć w pierwszych latach swojej działalności od zinów różnił je przede wszystkim większy nakład i oficjalna dystrybucja. W każdym razie i ziny, i czasopisma (w pełnym tego słowa znaczeniu) są „Zapisem ówczesnej świadomości i świadectwem potrzeby osób LGBT do posiadania własnej narracji”" . Narracji, która - przez osadzenie w gejowskim slangu - przenosi współczesnego czytelnika jeszcze bliżej „pedalskich” przestrzeni i problemów. Notabene, stąd wspomniane określenia „pedalski”, „ciotowski” zamiast „gejowski”. Wiąże się to oczywiście z początkiem emancypacji (homo)seksualnej w Polsce emancypacji ciot i pedałów ${ }^{10}$. Przełom lat 80 . i 90 . XX wieku to bowiem czas, kiedy nad leksemem „gej” dopiero dyskutowano — od strony formalnej (gay, gej, gejowie, geje, etc.) po semantyczną („Mamy tę szansę, że wprowadzamy nowe słowo, które jest ogółowi nieznane i mamy możliwość obudowania go pozytywnym znaczeniem"11). Tym bardziej uzasadnione jest w tym miejscu użycie określeń „pedalski” i „ciotowski” zamiast „gejowski” (który wówczas stanowił zaczątek do „projektu tożsamościowego" 12 rozwijanego przez całe lata 90 . $)^{13}$.

W artykule traktuję więc o przestrzeniach (rzeczywistych i mentalnych) ujętych w „pedalskich” („ciotowskich”, „gejowskich”) pismach, ich nazwach oraz wybranych

${ }^{5}$ Praktyczny słownik współczesnej polszczyzny pod red. Haliny Zgółkowej definiuje zin jako: „czasopismo o małym nakładzie, do niedawna wydawane przez amatorów, należące do pism alternatywnych; fanzin" (Zin, [hasło w:] Praktyczny słownik współczesnej polszczyzny, red. H. Zgółkowa, t. 49, Poznań 2004, s. 337.). O kryteriach, które musi spełniać zin, pisał również Wojciech Kajtoch w: W. Kajtoch, Co to jest zin?, „Ulica Wszystkich Świętych. Miesięcznik Mail Artu” 2001, nr 7 (21), s. 4.

6 Współcześnie ziny zalicza się do trzeciego obiegu, zob. K. Tomasik, Gayzety, „Replika” 2013, nr 44, s. 31-33.

7 „Filo” 1986, nr 3 (18), s. 2.

8 Czasopismo to „pismo redagowane kolegialnie, najczęściej przez zespół dziennikarzy, wydawane okresowo, w pewnych stałych terminach [...]"; Zob. Czasopismo, [hasło w:] Praktyczny słownik..., t. 7, Poznań 1996, s. 402.

9 K. Tomasik, op. cit., s. 32.

10 Z kolei Błażej Warkocki emancypację okresu 1981-1990 r. nazywa wstępną fazą emancypacyjną, emancypacją „innych”. Emancypacja gejowsko-lesbijska przypada dopiero na lata 1990-2003. Zob. B. Warkocki, Trzy fale emancypacji homoseksualnej w Polsce, „Porównania” 2014, nr 15, s. 121-132.

11 „Można nawet postarać się o definiowanie geja jako świadomego pedała, który chce walczyć o swoje prawa i szerzyć aktywnie tolerancję [...]”. Zob. R. Placyd, O słowie gej, „Filo” 1988, nr 2 (14), s. 12.

12 B. Warkocki, op. cit., s. 126.

13 Michał Witkowski w Lubiewie bez cenzury pisze, że „[g]eje są wytworem późnej fazy liberalnego, konsumpcyjnego kapitalizmu w Stanach Zjednoczonych i Europie Zachodniej [...]. Geje — w przeciwieństwie do ciot - w pełni akceptują kapitalistyczne społeczeństwo, którego są wytworem [...]”. Zob. M. Witkowski, Lubiewo bez cenzury, Warszawa 2014, s. 397. 
nazwach nierozerwalnie $\mathrm{z}$ tymi przestrzeniami związanymi. Jednocześnie warto zauważyć, że już same ziny tworzą jedną z nich, tj. przestrzeń komunikacji społeczności gejowskich, która w latach 80. i 90. XX wieku była ewidentnie utrudniona (a w małych miejscowościach wręcz niemożliwa), zwłaszcza że o komunikowaniu się za pomocą Internetu (wówczas jeszcze usługi sieciowej IRC) zaczęto pisać (w „Inaczej” i w „Filo”) dopiero w połowie lat 90. Dlatego to właśnie prasa stała się „czymś w rodzaju gejowskiej agencji informacyjnej" ${ }^{14}$, miejscem wymiany wiadomości, doświadczeń społeczności - i mowa tu nie tylko o tekstach redakcji, ale przede wszystkim o rubrykach tworzonych przez czytelników, np. opowiadania, listy do redakcji czy ogłoszenia towarzyskie (koncerty życzeń [OZ, 91, 1(4), 23 $]^{15}$ ).

\section{Na pikiecie: w parku, w toalecie}

Przestrzeń publiczna jest heteroseksualna. Z założenia i z doświadczenia. Moment, w którym pojawia się w niej narracja homoseksualna, zwraca uwagę heteronormatywnych przechodniów. W końcu miejsce to zostaje przejęte i odarte $\mathrm{z}$ seksualności, którą znają. Przejęte i rekontekstualizowane. Zmierzam do tego, że przestrzeń rzeczywista (fizyczna) może być - po pierwsze - dedykowana gejom wprost, jak gay cluby albo - po drugie - może być przez gejów zaadaptowana na własne potrzeby. W drugim przypadku, kiedy dochodzi do subwersywnych działań polegających na wykorzystywaniu heteroseksualnych barów jako miejsc spotkań albo uprawianiu gejowskiego seksu w miejscach publicznych; saunach, dworcowej toalecie czy przy zakrzewionym skwerze, tworzą się miejsca nowe, tj. o nowym znaczeniu ${ }^{16}$. Heterotopie, w których nakładają się na siebie dwa wymiary - hetero- i homoseksualny. W rzeczywistości ten drugi jest ukryty, ale nie fizycznie - po prostu nie występuje w ogólnospołecznej świadomości, tworząc kontr-miejsce, świat alternatywny czy w końcu - efektywnie odgrywaną utopię ${ }^{17}$. W ten sposób dla jednych Centralny jest tylko dworcem PKP, a dla - nomen omen - innych już giełda albo Broadwayem. Podobnie rzecz ma się z parkiem. „[P]ark nazywa się "pikieta« albo »szlak«. Chodzenie po nim to pikietowanie. Pikieta służy do wyrywania. Podrywania, znaczy. Celem obciągu. Drutowania, znaczy"18.

14 K. Tomasik, op. cit., s. 32.

15 Dla przejrzystości wywodu, przy wyrazach i wyrażeniach slangowych pochodzących z konkretnych pism, będę stosował zapis: [tytuł, rok, nr pisma, nr strony], kolejno dla: „Efebos” [E], „Filo” [F], „Inaczej” [I], „Nowy Men” [NM], „Okay” [O], „O Zmierzchu” [OZ].

16 B. Lis, Seksualne obywatelstwo i nieheteronormatywne doświadczanie przestrzeni, „Kultura Popularna” 2009, nr 2 (24), s. 104-112.

17 M. Foucault, op. cit.

18 M. Witkowski, op. cit., s. 20. 
Subwersja przestrzeni publicznej, o której pisze m.in. Bartłomiej Lis w Seksualnym obywatelstwie..., jest o tyle istotna, że przedstawiana w tym tekście leksyka socjolektalna dotyczy w większości miejsc właśnie rekodowanych, wszakże gay cluby (z darkroomami) i inne lokale dedykowane gejom zaczęto otwierać dopiero w latach 90. Do tego czasu społeczności ciotowskie (pedalskie) takie miejsca musiały tworzyć samodzielnie, co wiązało się z adaptacją (a przez to z subwersją) już istniejących pierwotnie heteroseksualnych.

Pikieta [I, 94, 10(52), 8-9; 36] jest bodaj najpopularniejszym frekwencyjnie leksemem socjolektu gejowskiego. Oznacza miejsce spotkań osób homoseksualnych, park, toaletę, łaźnię. Praktyczny słownik współczesnej polszczyzny pod redakcją Haliny Zgółkowej - jako jeden z nielicznych — podaje definicję, zaznaczając jej środowiskową etymologię: „określone miejsce (np. kawiarnia, park, ubikacja), w którym spotykają się homoseksualiści w celu nawiązywania kontaktów" ${ }^{19}$. Podobną definicję podaje Klemens Stępniak w Słowniku gwar środowisk dewiacyjnych, dodając, że pikieta to również: „dworzec kolejowy”, a „latać na pikiet” czy „chodzić na pikietę" to „uprawiać prostytucję" 20 , na co wskazuje wyżej wspomniany cel pikietowania - podryw. Znaczącym wydaje się również brak odmiany (w tym przypadku) w bierniku „latać na pikiet”, zamiast „na pikietę”, co w slangu gejowskim stanowi już cechę dystynktywną, zwłaszcza w społeczności nie tyle gejowskiej co ciotowskiej (przeginanie [I, 92, 26, 8]), np. „Jadę do Sopot”21 [F, 90, 2(20), 48-49], „Przyjechawszy wreszcie do dom” [NM, 96, 1, 68]. Inny słownik języka polskiego pod redakcją Mirosława Bańki, mimo że nie odnotowuje żadnego ze znaczeń środowiskowych (pikieta to również miejsce spotkań prostytutek [ biniawera $^{22}$ ] oraz przestępców i chuliganów [gwara przestępcza/chuligańska] $)^{23}$, zaznacza, że jest to słowo przestarzałe i odnosi się do "grupy żołnierzy wyznaczonych do ochrony czegoś" ${ }^{24}$, co pokrywa się z jedną z definicji Praktycznego słownika mówiącą o stojącym na straży pojedynczym żołnierzu lub całym oddziale. I gdyby szukać tu dalszych powiązań, dotrzemy do Lubiewa Michała Witkowskiego, w którym cioty opowiadają o pikietowaniu w koszarach jeszcze w latach 80., kiedy w Polsce stacjonowali rosyjscy żołnierze („Żałuj, Michaśka, że cię wtedy na świecie nie było"25).

19 Pikieta, [hasło w:] Praktyczny słownik..., t. 28, Poznań 2000, s. 374-375.

20 Pikieta, [hasło w:] K. Stępniak, Słownik gwar środowisk dewiacyjnych, Warszawa 1986, s. 176.

21 W kontekście: „jesteście w stolicy ciotowskiej Gdańsku-Sopocie. Cioty mówią zresztą »Jadę do Sopot «".

22 Biniawera to nazwa żargonu prostytutek, zob. S. Grabias, Język w zachowaniach społecznych, Lublin 1997, s. 144.

23 Por. Pikieta, [hasło w:] Praktyczny słownik..., s. 374-375; oraz K. Stępniak, op. cit., s. 176.

24 Pikieta, [hasło w:] Inny słownik języka polskiego, red. M. Bańko, Warszawa 2000, s. 70.

25 M. Witkowski, op. cit., s. 35. 
Nieodłączną cechą każdej cioty jest przeginanie [się] [I, 92, 26, 8], czyli „udawanie kobiety $[. .$.$] - wymachiwanie rękami, piszczenie, mówienie »ależ przestań«i »Boże$ Bożenka " ${ }^{26}$, zachowując się niczym „poprzeginane gwiazdy, które zastałbyś w kawiarni, omdlewająco wsparte o bufety lub siedzące przy stolikach w nieprawdopodobnych pozach (ty [...] - nigdy byś nie umiał tak pozaplatać nóg)"27. Ważnym elementem przeginania (zmanierowania) jest język - obok charakterystycznych fraz („Boże Bożenka”, etc.) istotną rolę odgrywają pseudonimy (najczęściej rodzaju żeńskiego), częste użycie deminutiwów oraz mówienie o sobie w rodzaju żeńskim - emocjonalnie, specyficznym, przerysowanym tonem. Całość tworzy kampowa przestrzeń, gejowską scenę, kabaret, które stają się rzeczywistością ciotowskiej społeczności „jeżdżącej do Sopot” i „biegającej na pikiet”28.

Broadway [O, 90, 1, 3-4], zapisywany również jako: Brodway [I, 91, 9, 15], broodway [I, 91, 10, 3] oraz fonetycznie: brodłej [I, 96, 1(67), 16-17], w zależności od kontekstu oznacza okolice Pałacu Kultury w Warszawie, Dworzec Centralny (w ogóle) albo (już dokładniej) zakątki peronu czwartego oraz - powtarzając za definicją w Tęczowym elementarzu Roberta Biedronia: „Broodway - miejsce spotkań mężczyzn homoseksualnych w celu znalezienia partnera (park, toaleta publiczna)"29. Ostatnie pojęcie desygnuje jednocześnie dowolną pikietę, z czym o tyle trudno mi się zgodzić, że w omawianych pismach Broadway (bez względu na zapis) zawsze dotyczył tej jednej, konkretnej, zlokalizowanej w Warszawie, mimo nieścisłości pojawiających się przy dokładnym jej wyznaczeniu - między Dworcem Centralnym a Pałacem Kultury. Z rozwiązaniem problemu przychodzi więc „HomoWarszawa” ${ }^{30}$, która Broadway rozrysowuje od podziemi Centralnego przez aleje handlowe (jedna z nich zwana była galeriq ${ }^{31}$, gdyż obserwowano w niej przyjezdnych lujów (heteroseksualnych mężczyzn) [I, 94, 1(43), 29]) do wyjścia przed Pałac Kultury i na toaletach na siódmym, i ósmym piętrze w tymże kończąc $c^{32}$.

Sama etymologia nazwy nie została nigdzie sprecyzowana, choć geje zwykli nazywać przestrzeń tę Broadwayem głównie dlatego, że stanowiła najpopularniejszy deptak w stolicy - najczęściej uczęszczany nie tylko przez tubylców, lecz także przyjezdnych na gościnne występy [F, 92, 7(38), 10] ${ }^{33}$ (co tłumaczy bliskość dworca PKP).

26 Ibidem, s. 15.

27 Za mundurem, „Inaczej” 1991, nr 17, s. 8-9.

${ }^{28}$ Kwestia przeginania społeczności ciotowskiej i jej kampowość jest problemem dużo bardziej złożonym (i wymagającym osobnego nań spojrzenia), dlatego - na potrzeby artykułu — zaznaczam wpływ tychże na leksykę slangu gejowskiego bez ich obszernej analizy.

29 R. Biedroń, Tęczowy elementarz: czyli (prawie) wszystko, co chcielibyście wiedzieć o gejach i lesbijkach, Warszawa 2007, s. 118.

30 Y. Kostrzewa et al., HomoWarszawa: przewodnik kulturalno-historyczny, Warszawa 2009.

31 Ibidem, s. 18.

32 Ibidem, s. 13-46.

33 Gościnne występy oznaczają pikietowanie poza miejscem zamieszkania. 
Z drugiej strony przeginanie rzeczywistości - jej przejaskrawienie, tworzenie świata alternatywnego na przykładzie m.in. znanych metropolii czy produkcji telewizyjnych $^{34}$ (np. nazwanie Parku im. Marcinkowskiego w Poznaniu - Mogadorem [NM, 95, 6, 68], a uczęszczających tam gejów - w nawiązaniu do popularnego wówczas serialu Panie na Mogadorze - damami lub pannami ${ }^{35}$ ) pozwalała ciotom nie tylko udawać gwiazdy, ale przy całej swej kampowej ${ }^{36}$ kreacji odebrać to, co zabrało im heteronormatywne społeczeństwo - chwilę uwagi. Notabene, Słownik nazw własnych Jana Grzeni określa Broadway jako „ulicę w Nowym Jorku”37. „Wikipedia” uzupełnia ten opis m.in. o „liczne teatry” $\mathrm{i}$ „centrum kulturowo-rozrywkowe USA" ${ }^{\text {" }}$. W tym przypadku jest to więc „centrum kulturowo-rozrywkowe Ciotolandu”.

Różnorodność chrematonimów ${ }^{39} \mathrm{w}$ gejowskiej przestrzeni skłania do napisania osobnego artykułu, dlatego podaję tu tylko wybrane przykłady. Ciotoland $[I, 92,28,10]$ można traktować zatem jako nazwę własną konkretnego lokalu (w Lubiewie Witkowskiego rekodowany został bar należący do „Orbisu”, nazywany też "Małą Ciotką" i „Ciociobarem”40) lub jako określenie społeczności wraz z jej przedstawicielami - w myśl alegorii państwa (i jego obywateli). Sufiks -land stanowi bowiem „część wyrazów złożonych oznaczających miejsca związane z tym, co nazywa pierwszy człon złożenia" ${ }^{41}$. Społeczność staje się więc mentalną przestrzenią, którą można zlokalizować w jej architekturze w przestrzeni rzeczywistej (pikiety, trakty, galerie, ściany płaczu, etc.). W opozycji do Ciotolandu stoi Ciemnogród $[\mathrm{O}, 90,1,0]^{42}$. Stąd alegoria państw wrogich — odmiennych światopoglądowo („Ciemnogród najchętniej ukamieniowałby wszystkich »odmieńców«. Horyzont myślenia ciemnogro-

34 „Smak ukształtowany przez kamp odczuwa pociąg do pewnego rodzaju dzieł sztuki, a więc cioty żyją w świecie seriali, telenowel, katalogów mody. Uwielbiają Dallas, Powrót do Edenu, Pótnoc-Południe, Dynastię [...]"; Z. Dimoski, Język i stylizacja w wybranych utworach homoerotycznych (Macedonia, Chorwacja, Polska), [w:] Tabu w oku szeroko otwartym, red. N. Długosz (współpraca: Z. Dimoski), Poznań 2012, s. 41.

35 Zasłyszane od rodzimego poznaniaka.

36 Zob. L. Parys, Kamp według Susan Sontag, „Dyskurs. Pismo Naukowo-Artystyczne ASP we Wrocławiu" 2014, nr 17, s. 74-91.

37 Broadway, [hasło w:] J. Grzenia, Słownik nazw własnych, Warszawa 2003, s. 113.

38 Broadway, [hasło w:] Wikipedia, pl.wikipedia.org/wiki/Broadway_(Manhattan) [dostęp: 5 stycznia 2016].

39 Najwięcej chrematonimów znaleźć można wśród gejowskich klubów, kawiarni i barów oraz pikiet (np. Spalona, Artystyczna czy — wspomniana na początku tego artykułu — Pod Obrazem, czyli przy Panoramie Racławickiej we Wrocławiu).

40 M. Witkowski, op. cit., s. 47.

41 Land, [hasło w:] Słownik języka polskiego PWN, www.sjp.pwn.pl/slowniki/Land [dostęp: 5 stycznia 2016].

42 Warto zauważyć, że już sam kontrast „land” — „gród” jest znaczący, sufiks „-land” bowiem konotuje przestrzeń nowoczesną i otwartą, „gród” natomiast nawiązuje do średniowiecznej, zamkniętej otoczonej wałem lub murem osady. 
du ograniczony jest bowiem małżeńską pierzyną"43), broniących granic i wolności. Walczących o własną narrację.

Amerykańscy geje mają swoje tearooms (herbaciarnie), francuscy pissoirs (szczalnie), a w Anglii i krajach będących pod wpływem terminologii brytyjskiej - cottages $(\text { chatki })^{44}$. W polskim gejowskim slangu szalety — obok najpopularniejszej, choć bardzo ogólnej pikiety - funkcjonowały też pod pojęciami motywowanymi ich budową: blaszak [I, 2000, 2(116), 24], grzybek [I, 96, 1(67), 16-17], zielona budka [F, 96, 2 (75), 20]. Wnętrze toalet dzielono zwykle na dwie części. Z jednej strony były kabiny, które jeszcze przed pojawieniem się pedalskich pism pomagały w wymianie informacji i nawiązywaniu nowych kontaktów (kabinalia [I, 97, 1 (79), 31], ogłoszenia [O, 90, 1, 19-20]; „Jeśli już wchodziłem do kabin, to ze względu na napisy na ścianach [...]. To był erzac pikantniejszej prasy gejowskiej, która miała się dopiero pojawic" ${ }^{45}$ ) oraz pełniły funkcję tzw. telewizornii [I, 94, 10 (52), 36]. Podglądactwo to bowiem kolejna pedalska cecha. W ścianie między kabinami robiono więc dziurę, współcześnie zwaną glory hole ${ }^{46}$, czyli dziurą chwały, ówcześnie zaś dziurką kontaktowa [I, 94, 10 (52), 36] lub druślakiem ${ }^{47}$ (przez konotację z durszlakiem). Po drugiej stronie kabin mocowano pisuary określane katalogami [O, 90, 5, 25-26] lub ściana płaczu [F, 91, 7 (31), 8-9], przy której - zgodnie z etykietą toaletowego seksu - pikietowano z obnażonym penisem.

Pikiety nazywano również giełdami [F, 89, 3 (18), 10]. Słownik gwar środowisk dewiacyjnych jako jedną z definicji giełdy podaje „miejsce spotkań homoseksualistów”48. Ponadto - obok parków i toalet - spotykano się także w miejskich łaźniach i saunach. Te nazywano parówami [OZ, 91, 1 (4), 22] albo - jeśli miały charakterystyczną, wydłużoną budowę - tramwajami [O, 90, 1, 19-20]. W łaźniach, zwykle pod prysznicami, działał wybieg [I, 94, 10 (52), 36], który „dla młodych był miejscem pierwszej konfrontacji własnego ciała ze wzrokiem kąpiących się w basenie"49.

Innymi przestrzeniami są już te, których rekodować nie trzeba, które z definicji są miejscami gejowskimi, jak np. gay cluby i darkroomy — „ciemne pokoje”, pomieszczenia przeznaczone do anonimowego seksu, które z powodzeniem zastąpiły współczesnym gejom tradycyjne pikiety.

43 Od Redakcji, „Okay. Miesięcznik dla panów” 1990, nr 1.

44 Ch. Silverstein, F. Picano, Radość seksu gejowskiego, przeł. D. Kołaczkowski, Warszawa 2009, s. $372-375$.

45 Zakazane piosenki, „Inaczej“ 1997, nr 1 (79), s. 31.

46 Ch. Silverstein, F. Picano, op. cit., s. 372.

47 J. Snarski, Wrocławskie kawiarnie za czasów PRL - przyjazne gejom, [w:] homiki.pl/index. php/2010/05/wrocawskie-kawiarnie-za-czasw-prl-przyjazne-gejom [dostęp: 5 stycznia 2016].

48 Giełda, [hasło w:] K. Stępniak, op. cit., s. 72.

49 Starych pikiet czar, „Inaczej” 1994, nr 10 (52), s. 36. 


\section{W szafie}

Gdzie jest gej? Na pikiecie. W darkroomie. W odbycie. Może być w środowisku, poza nim, w getcie albo na scenie. Gdziekolwiek by jednak nie był - (jednocześnie) zawsze może być w szafie. Błażej Warkocki w Różowym języku pisze, że w latach 90. — w sensie kulturowym - wszyscy byli w szafie, bo nie było innej opcji. Taki świat bez (publicznie istniejących) gejów, których zawieszono gdzieś pomiędzy pomyślanym a wypowiedzianym, między realnym a fantazmatycznym ${ }^{50}$. Tym trafniejsze są tu słowa Kingi Dunin, że w Polsce drugiej połowy XX wieku homoseksualizm „istniał i jednocześnie nie istniał" 51 . Zszedł do podziemia, miał swój język, ciotowską subkulturę, pikiety i ziny, miał swoją scenę i maskaradę. Miał swoją maskę. Miał szafę.

Wyrażenia wychodzić/wyjść $z$ szafy (ang. coming out of the closet, w skrócie coming out) w słownikach języka polskiego XX i początku XXI wieku nie znajdziemy. Powtarzając więc definicję z Coming out Małgorzaty Kity, wyjście z szafy to „(publiczne) ujawnienie nieheteronormatywnej seksualności przez osobę, której to dotyczy" 52 . W pedalskich pismach lat 80. i 90. XX wieku, w dyskusjach dotyczących tożsamości i funkcjonowania w społeczeństwie (współcześnie nazwalibyśmy je próbą kreowania wizerunku ówczesnych gejów: jak się (nie) zachowywać, gdzie (nie) bywać i o czym (nie) pisać, gdyby pismo czytali również heteroseksualni), coming out określano $w y j$ ściem: $z$ ukrycia [F, 90, 2(20), 35-37] $z$ podziemia [I, 90, 1, 5], $z$ getta [I, 91, 11, 3]. Należy przy tym zauważyć, że wszystkie trzy przestrzenie (w tym kontekście - mentalne) nie są wcale nacechowane neutralnie. Wręcz przeciwnie - każde z nich odsyła do wartości negatywnych: strachu i braku zaufania, nietolerancji, w końcu: represji i przymusu zamknięcia, i ostatecznego odizolowania. Dodatkowo w gwarze więziennej gettem nazywa się „najniższą kastę więźniów w celi, pogardzanych i wykorzystywanych $[\ldots]^{\prime 53}$. Dlatego też to, co z jednej strony wydawałoby się bezpieczne (wszak szafa ${ }^{54}$ gwarantowała odcięcie się od normatywnych ocen), z drugiej - ograniczało wolność i prowadziło do Gombrowiczowskiego upupienia - spętania (hetero)formą.

Redakcje pedalskich pism końca XX wieku namawiały więc czytelników, aby „wyjść z getta, zaakceptować siebie, żyć zgodnie ze sobą i w zgodzie ze społeczeństwem, któ-

50 B. Warkocki, Anatomia szafy, [w:] idem, Różowy język. Literatura i polityka kultury na początku wieku, Warszawa 2013, s. 19-51.

51 Cyt. za: K. Tomasik, Gejerel. Mniejszości seksualne w PRL-u, Warszawa 2012, s. 10.

52 M. Kita, Coming out. Nowy gatunek na polskiej mapie genologicznej, zdarzenie komunikacyjne, wydarzenie medialne, [w:] O płci, ciele i seksualności w języku i mediach, red. M. Karwatowska et al., Lublin 2014, s. 323.

53 Getto, [hasło w:] K. Stępniak, op. cit., s. 71.

54 O tym, dlaczego akurat „szafa” oraz o „trupie w szafie” i tabu pisali już: B. Warkocki i A. Laszuk; B. Warkocki, op. cit., s. 19-55; A. Laszuk, Queer po polsku, czyli nowoczesny closet, „Interalia. Pismo poświęcone studiom queer” 2010, nr 5, http://interalia.org.pl/pl/artykuly/2010_5/03_queer_po_polsku_czyli_nowoczesny_closet.htm [dostęp: 5 stycznia 2016]. 
re powinno nas tolerować [w ogóle, a] nie dlatego, że się ze swoją »innością u ukrywamy"55. Jacek Kochanowski w Fantazmacie zróżNICowanym zaznacza zresztą, że gejem jest tylko ten, kto za geja się uważa. Podkreśla przy tym, by gejem nie być, ale wciąż się gejem stawać (w nawiązaniu do Drugiej $p \nmid i^{56} \mathrm{~S}$. de Beauvoir, która pisze, że nikt kobietą się nie rodzi, ale dopiero się nią staje ${ }^{57}$. O nieustannym stawaniu się mówi również Judith Butler w „Uwikłanych w płeć” ${ }^{2}$. Według niej trwamy w spektaklu bez końca, wchodząc w role wynikające ze społecznych i kulturowych oczekiwań wobec płci, którą przypisuje się nam zaraz po urodzeniu, wypowiadając magiczne: "to chłopiec” albo „to dziewczynka”, niosące z sobą cały repertuar cech, zachowań i stereotypów, ponieważ już „od chwili narodzin przestajemy być sobą, a stajemy się kims $^{\prime \prime 59}$, przyjmując narzucane nam, gotowe konstrukcje - (hetero)formy.

Coming out jest więc z założenia wypowiedzią pierwszoosobową - deklaracją, performatywem, który wprowadza wyoutowanego do środowiska (społeczności gejowskiej), choć samo środowisko [I, 2001, 6 (132), 8-11] nie zawsze wartościowane jest pozytywnie. Wręcz przeciwnie. Próba wyoutowania stawia podmiot między negatywnie nacechowanymi gettem a środowiskiem - dwiema przestrzeniami mentalnymi, z których pierwsza ogranicza jednostkę przez przyjęcie formy heteronormatywnej, druga zaś ogranicza ją, sprowadzając do stereotypu rozwiązłości i zniewieścienia. Przestrzeń pomiędzy nimi wypełnia tzw. poza-środowisko, używane najczęściej w ogłoszeniach towarzyskich: „Przystojny, dyskretny, trzydziestoletni »Bis« pozna odpowiedniego partnera spoza środowiska". Wyrażenie to początkowo miało nobilitować tego spoza w oczach nowo poznanego mężczyzny, z czasem jednak stało się bezwartościowym sloganem większości ogłoszeń, utartym hasłem pozbawionym pierwotnego znaczenia: „»Spoza środowiska « - to określenie robiło, robi i prawdopodobnie będzie nadal robiło furorę w ogłoszeniach [...]. Dla jednych jest oczywistym wyrazem oczekiwań kierowanych wobec partnera, a dla innych szczytem hipokryzji i zakłamania"60.

Jerzy Krzyszpień (Język i emancypacja LGBT) proponuje nawet zastąpienie kontrowersyjnego środowiska społecznością. Jak wyjaśnia, społeczność (ang. community) „wskazuje na ludzi, których coś łączy. [...] niefortunny wyraz środowisko wskazuje bardziej na warunki życia, pracy bądź prowadzenia innej działalności”' ${ }^{\prime}$. Ponadto środowisko używane jest często w opisach krytycznych, np. „środowisko przestępcze”. Praktyczny słownik współczesnej polszczyzny dopełnia tę definicję o „grupę ludzi

55 Prawdy i pótprawdy o „Lambdzie”, „Inaczej” 1991, nr 11, s. 3.

56 S. de Beauvoir, Druga płeć, przeł. G. Mycielska, M. Leśniewska, Warszawa 2014.

57 J. Kochanowski, Tożsamość gejów - wstępne rozpoznanie, [w:] idem, Fantazmat zróżNICowany. Socjologiczne studium przemian tożsamości gejów, Kraków 2004, s. 157-169.

58 J. Butler, Uwikłani w płeć. Feminizm i polityka tożsamości, przeł. K. Krasuska, Warszawa 2008.

59 J. Kochanowski, op. cit., s. 40.

60 Ja ze środowiska, „Inaczej” 2001, nr 6 (132), s. 8-11.

61 J. Krzyszpień, Język i emancypacja LGBT: uwagi praktyczne, [w:] Queer Studies. Podręcznik kursu, red. M. Abramowicz, R. Biedroń, J. Kochanowski, Warszawa 2010, s. 144. 
mających te same zainteresowania, zasady moralne"62 - choć to środowisko akurat zdaje się być tych zasad pozbawionym: „Nie chcę mieć nic wspólnego z tzw. środowiskiem gejowskim. Same intrygi, zdrady, obłuda!"63.

Trafniejszym byłoby więc nazywanie tej przestrzeni subkultura, definiowaną jako „wzorce, normy przyjęte nieformalnie i obowiązujące przedstawicieli danej grupy społecznej [...], różniące się zasadniczo od wzorców, norm przyjętych przez społeczeństwo" ${ }^{34}$. W rzeczywistości synonimem tejże w slangu gejowskim jest scena [F, 90, 1 (19), 11-12] wartościująca zwykle pozytywnie (rzadziej neutralnie): „Łagodniejszą formą "getta « jest funkcjonowanie tzw. »Sceny« czy »Subkultury«"65; „[Gejowska scena] jest dobra dlatego, że chociaż przez chwilę pozwala młodym ludziom być sobą" ${ }^{\prime \prime 6}$. Pojmowana w ten sposób subkultura implikuje teatr (heterotopię per se), z tą tylko różnicą, że w teatrze zwykło się maskę przybierać - na tej scenie zaś maskę tę można w końcu zrzucić.

\section{W dupie}

Pisma przełomu lat 80. i 90. XX wieku odegrały znaczącą rolę w edukowaniu gejowskiej społeczności. Głównie $\mathrm{w}$ tematach tożsamościowych oraz propagowania bezpiecznego seksu (przede wszystkim w kontekście epidemii AIDS). Choć w Polsce akurat problemu HIV/AIDS nigdy nie było, bo - jak pisze Krzysztof Tomasik w Gejerelu - Polacy mają tylko dwa związane z tą epidemią okresy: kiedyś „przed” i teraz „po" ${ }^{\prime 67}$. AIDS istniało więc poza powszechnym dyskursem, jakby publiczne media miały tylko heteroseksualnych odbiorców.

Dupe, za Innym słownikiem, traktuję „,bardzo potocznie" ${ }^{68}$, choć dla wielu jest wulgarna. Dla mnie stanowi przede wszystkim kolejną gejowską przestrzeń wartą rozważenia. Po pierwsze, dlatego że w odniesieniu do pytania Lea Bersaniego „Czy odbytnica jest grobem?”69 docieramy do zaznaczonego wyżej problemu AIDS - sprowadzanego zwykle przez ówczesne media głównego nurtu do choroby wenerycznej, konsekwencji analnych aktów seksualnych i - w końcu — winnych wszystkiemu gejów ${ }^{70}$. Dalej: do pogrzebania w tymże grobie ideałów męskości i męskości per se w ogóle, do wiedzy/

62 Środowisko, [hasło w:] Praktyczny słownik..., t. 42, Poznań 2003, s. 131.

63 Zawsze dziewica, „Inaczej” 2002, nr 2 (140), s. 14-15.

64 Subkultura, [hasło w:] Praktyczny słownik..., t. 40, Poznań 2003, s. 456.

65 Ruch Homoseksualny w Polsce. Dlaczego? Dla kogo? W jaki sposób?, „Filo” 1990, nr 1 (19), s. 11-12.

66 To idzie młodość, „Inaczej” 2000, nr 7 (121), s. 6-10.

67 Zob. K. Tomasik, AIDS, którego nie było, [w:] idem, op. cit., s. 223-263.

68 Dupa, [hasło w:] Inny stownik..., s. 330.

69 L. Bersani, Czy odbytnica jest grobem?, przeł. M.A. Pelczar, [w:] Teorie wywrotowe. Antologia przekładów, red. A. Gajewska, Poznań 2012, s. 745-782.

70 Ibidem, s. 748-766. 
władzy Michela Foucaulta i do analnego tabu. Oraz — po drugie - do stereotypu (ale czy tylko?), że "pedalski świat kręci się wokół dupy"71, na co w slangu gejowskim wskazuje frekwencyjnie największa grupa leksemów dotyczących czynności seksualnych.

Być $w$ dupie to zgodnie z definicją Miejskiego słownika slangu „znaleźć się w sytuacji bez wyjścia, zgubić się lub mieć problem" ${ }^{\prime 2}$. W takiej sytuacji znaleźli się właśnie ci, których dotknęła grypa lub zaraza [E, 87, 1, 1], czyli w rzeczywistości sprowadzone do niewypowiadalnego tabu - AIDS. Zamiast medialnych „kolejnych ofiar”, mówiono: „Seba także nie żyje - grypa"73 - przez eufemizmy miało być łatwiej, mimo że pedalskie pisma wiedziały, że łatwiej już nie będzie, dlatego w każdym numerze pojawiał się co najmniej stronnicowy tekst o profilaktyce HIV/AIDS, o bezpiecznym - a z czasem już tylko bezpieczniejszym seksie (ang. safer sex) i hiperbolizowanych zarazach. Problem bowiem polegał na tym, że przez nieznajomość, inność wirusa/ choroby — ogół białego, heteroseksualnego społeczeństwa sam wskazał (w)innych: gejów i narkomanów. Strzykawki i analny seks. Brud i odbyt ${ }^{74}$.

Granicę tolerancji osób homoseksualnych stanowi pasywny seks analny. Niemal wszystkie kultury (przez konotację do stosunku waginalnego) wiążą bierne uczestnictwo w akcie seksualnym z kobiecością. Dodatkowo tabu analne wzmacnia fobie wobec (seksualnych zachowań) gejów ${ }^{75}$. Wyrażenie dać dupy definiuje się jako - po drugie — „o partnerze biernym: zgodzić się na stosunek seksualny” oraz - po pierwsze - „poddać się, przegrać”76, „skompromitować się”, „zrobić coś źle, nagannie”, „postąpić bez godności”77. W gwarze więziennej już sama dupa oznacza „karę pozbawienia wolności za pobicie lub zgwałcenie kobiety albo za gwałt homoseksualny"78, zaś wyrażenie grać o dupę odnosi się do "gry więziennej, w której przegrany staje się homoseksualistą"79. Należy zauważyć, że tylko zgoda na stosunek seksualny jest leksykograficznie (ale czy społecznie?) neutralna. Pozostałe definicje odwołują się do wartości negatywnych, od kompromitacji po brak godności. W grze homoseksualistą

71 S. Starosta, Notatki malkontenta: Pamiętajmy o dupie, „Inaczej” 1991, nr 10, s. 5.

72 Być $w$ dupie, [hasło w:] Miejski słownik slangu i mowy potocznej; www.miejski.pl/slowo-Być+w+dupie [dostęp: 5 stycznia 2016].

73 Zasłyszane (wypowiedź 68-letniego geja, styczeń 2015).

74 L. Bersani zaznacza, że Zachód używał problemu AIDS jako pretekstu do prawnej regulacji i manipulacji grup społecznie nieakceptowanych. Amerykańscy eksperci ds. HIV/AIDS, media — a za nimi część białego, heteroseksualnego społeczeństwa obarczali winą gejów, ich rozwiązły styl życia oraz rodzaj uprawianego seksu. Ostatecznie z gejów-ofiar (grupa największego ryzyka) zrobiono zabójców. Zob. L. Bersani, op. cit., s. 745-782.

75 J. Morin, Konfrontacja z tabu seksu analnego, [w:] idem, Radość seksu analnego, przeł. K. Wolański, Warszawa 2014, s. 35-48.

${ }^{76}$ Dupa, [hasło w:] Wielki słownik frazeologiczny PWN z przysłowiami, oprac. A. Kłosińska, E. Sobol, A. Stankiewicz, Warszawa 2005, s. 86-87.

77 Dupa, [hasło w:] Praktyczny słownik..., t. 9, Poznań 1996, s. 370-373.

78 Ibidem.

79 Dupa, [hasło w:] K. Stępnik, op. cit., s. 54. 
staje się przegrany, homoseksualność jest więc karą, a porównanie homoseksualnego gwałtu do zgwałcenia kobiety po raz kolejny implikuje stereotyp przeginającego się geja i „nieznośny obraz dorosłego mężczyzny, który nie potrafi odmówić sobie samobójczej ekstazy bycia kobietą" $"$.

Odbytnica jest więc grobem tych, którzy szukają w niej przyjemności, oraz tego, co zwykło nazywać się męskim ideałem podmiotowości, tj. przekonania, że godne zachowanie mężczyzny zawiera się tylko w aktywnym, dominującym penetrowaniu desygnującym siłę i władzę ${ }^{81}$. Cioty natomiast z grobu zrobiły Broadway, Disneyland - Ciotoland, centrum kulturowo-rozrywkowe $\mathrm{z}$ teatrem i scena do przeginania feminizowania męskiego ciała. Karnawał w Rio De Galop ${ }^{82}$ - maskarada, kabaret i błazenada. Skandal. Wszystko na opak i od dupy strony ${ }^{83}$.

Tymczasem leksyka gejowskiego socjolektu desygnująca seks analny okazuje się być równie wartościującą i wulgarną. Podany w Praktycznym słowniku współczesnej polszczyzny przykład w „dupę jebać, ładować, rżnąć”, czyli „być aktywnym partnerem seksualnym"84, nie odbiega nacechowaniem od slangowych: ciąc dupe [I, 96, 1 (67), 63-66], zaliczać [I, 92, 29, 3], dupczyć [I, 94, 1 (43), 29], dźgać [I, 91, 14-15, 38], grzmocić [I, 92, 27, 30], (ze)rżnać [I, 91, 14-15, 38], pieprzyć [I, 95, 10 (64), 69], moczyć ogóra(sa) [F, 96, 9 (81), 51] czy - nawiązując do analnego tabu ${ }^{85}$ i kwestii estetyki, i czystości: mieszać kakao [F, 96, 9 (81), 51], mimo że określenia te wyrażają przecież nie tylko uległość ciot wobec lujów, lecz także partnerski stosunek dwóch gejów ${ }^{86}$. Niemniej jednak (taki) sposób desygnowania aktu seksualnego warunkuje postrzeganie zarówno samej sytuacji, jak i relacji z kochankiem, z którym kontakt ogranicza się do konkretnej części ciała. Seks bowiem - powtarzając za Arturem Rejterem (Mój chłopak, facet z plakatu, ciota darkroomówka) — „ma stanowić przede wszystkim źródło rozładowania napięcia, ale jest też źródłem rozrywki, ważnym elementem gejowskiego życia, klubowego lansu, które stanowią pochodną rozpowszechnianych przez kulturę masową wartości konsumpcjonizmu, zabawy, wygody, przygodnych związków międzyludzkich [i] dyktatu ciała"87.

80 L. Bersani, op. cit., s. 765.

81 Ibidem, s. 766, 780.

82 Zasłyszane: „Aleja od popiersia Marcinkowskiego do PKS to był Rio De Galop, ciotencje szybko [tamtędy] chodziły — robiły kilometrówkę".

83 Tu: „niepoprawnie, niezgodnie [z heteronormą]”, zob. Od dupy strony, [hasło w:] Miejski słownik slangu..., www.miejski.pl/slowo-Od+dupy+strony [dostęp: 10 stycznia 2016].

84 Dupa, [hasło w:] Praktyczny słownik....

85 Wiąże się to z koncepcją czystości fizycznej potrzebnej do osiągnięcia czystości duchowej oraz mówiąc wprost - z emocją obrzydzenia; zob. J. Morin, op. cit., s. 39.

86 Notabene, obok wyrażeń klasyfikowanych jako wulgarne pojawia się neutralny (bardzo rzadko): homoseks [F, 90, 2(20), wkładka] oraz pozytywnie konotujący (bo przez redakcje pism propagowany) bezpieczny/bezpieczniejszy seks (safe/safer sex) [I, 90, 3, 11]).

87 A. Rejter, Mój chłopak, facet z plakatu, ciota darkroomówka... Wizerunek mężczyzny w gejowskiej literaturze popularnej, [w:] Język artystyczny, red. A. Rejter, t. 15, Katowice 2014, s. 79. 


\section{Nigdzie}

Gdzie jest gej, który jest pomiędzy? Między realnym a fantazmatycznym? Między ukrytym a świadomym? Między pomyślanym a performatywnie wypowiedzianym? Czy pikieta jest już scena, czy tak naprawdę wciąż szafa? I czy siedząc $w$ getcie, nie siedzi się $w$ dupie?

W myśl przedstawionych $\mathrm{w}$ artykule wybranych gejowskich przestrzeni - realnych, mentalnych i przestrzeni-metafory - dupy, wokół której kręci się pedalski świat, należy mieć świadomość, że polskie realia przełomu lat 80. i 90. XX wieku zmusiły społeczności „pedalskie”, „ciotowskie” (i w końcu „gejowskie”) do subwersji przestrzeni niezbędnej we własnej identyfikacji - budowania tożsamości, do samodzielnego tworzenia miejsc przez przejmowanie i rekodowanie tego, co pierwotnie heteronormatywne, przez deklaracje odzierające je $\mathrm{z}$ heteroseksualnego charakteru. Istniejąc i nie istniejąc jednocześnie, albowiem gej jest przede wszystkim w języku. I dzięki językowi.

\section{Where is a gay? \\ On (names of) space in the first Polish gay magazines}

\section{Summary}

Gay zines of the 1980s and 1990s make up a unique communication space of gay communities at a time when communication was clearly problematic (and in small towns even impossible), especially given the fact that communication over the internet did not begin until the mid-1990s. That is why the press became a sort of gay information agency, a platform for information and experience sharing and most importantly - a record of the language of sexual minorities at the time.

In the article the author describes the spaces (real and mental) presented in gay magazines, their names and selected names (of things, types of behaviour etc.) inextricably linked to these spaces. In his research he draws on M. Foucault's concept of heterotopia and on the concept of subversion of space essential to the building of a gay community at the time. He points to the process of creating such spaces by taking over and recoding as well as redefining, in the gay sociolect, what was originally heteronormative. Finally, he draws a linguistic map of the spaces of gay culture. 